\title{
DRESSING IN WHITE, A TRUE BRAZILIAN TRADITION: SOCIAL INFLUENCE, VALUES AND SYMBOLIC CONSUMPTION
}

\author{
VESTIR-SE DE BRANCO, UMA VERDADEIRA TRADIÇÃO BRASILEIRA: \\ INFLUÊNCIA SOCIAL, VALORES E CONSUMO SIMBÓLICO
}

\author{
Submission: $12 / 05 / 2015$ \\ Accept: 30/06/2017 \\ Francisco Vicente Sales Melo ${ }^{1}$ \\ Salomão Alencar de Farias ${ }^{2}$ \\ Ohana Trajano Barbosa ${ }^{3}$
}

\begin{abstract}
This article seeks to understand how the individual interpretation of the social influence of groups and personal values relate to the symbolic consumption of white clothes in the festivities of New Year's Eve, a true Brazilian tradition. For that, we used a descriptive research design with personal interviews and survey, using thematic analysis and logistic regression. The results indicated that if it is necessary to be part of a group, people who value warm relations with others, fun and enjoyment, and who can modify their social self-presentation, are more likely to wear white clothes in this time of the year. Also, as for personal values, it was verified that if the use of white clothes favors the warm relations with others, fun, and enjoyment, there will be a high probability that one will wear white in the turn of the year. Our contribution relies on studying a typical Brazilian tradition that has an impact on apparel retailing sales and needs a better academic understanding. In terms of management, there is a clear indication of the social consumption of the clothes, and of group influence, which can be used in communications arguments from retailers to consumers.
\end{abstract}

Keywords: Social influence, values, symbolic consumption, New Year's Eve.

\footnotetext{
$1 \mathrm{PhD}$ in Business Administration from the Federal University of Pernambuco. Professor at the Department of Administrative Sciences at the Federal University of Pernambuco. Research interest: consumer behavior, marketing, transformative consumer research, quantitative methods. E-mail: vicsmelo@gmail.com. ORCID: https://orcid.org/0000-0003-0329-668X

2 Farias holds a bachelor's degree in Business Administration from the State University of Ceará (1987), a master's degree in Administration from the Federal University of Paraíba (1991) and a Ph.D. in Business Administration from the University of São Paulo (1998). Associate professor at the Federal University of Pernambuco and Visiting Professor at the Institute of International Business, Georgia State University. Research interest: consumer behavior, marketing, internet, service marketing, and consumer satisfaction. E-mail: saf@ufpe.br ORCID: https://orcid.org/0000-0001-5415-2606

$3 \mathrm{PhD}$ in Business Administration from the University of São Paulo, a master's degree in Administration from the Federal University of Pernambuco. Research interest: consumer behavior, marketing, and transformative consumer research.

E-mail: ohanatrajano@hotmail.com. ORCID: https://orcid.org/0000-0003-2966-0128
} 


\section{RESUMO}

Este artigo procura entender como a interpretação individual da influência social de grupos e os valores pessoais se relacionam com o consumo simbólico de roupas brancas nas festividades da passagem do ano, uma verdadeira tradição brasileira. Para tanto, realizou-se uma pesquisa descritiva com coleta de dados por meio de entrevistas pessoais e um survey, utilizando-se como técnicas analíticas a análise temática e a regressão logística. Os resultados indicaram que, se for necessário para fazer parte de um grupo, as pessoas que valorizam as relações calorosas com os outros, diversão e prazer, $e$ que tem a capacidade de modificar sua autoapresentação social, estão mais propensas a usar roupas brancas nesta época do ano. Além disso, quanto aos valores pessoais, verificou-se que se o uso de roupas brancas favorecer as relações calorosas com os outros, diversão e prazer, também haverá uma grande probabilidade de as pessoas usarem roupas brancas na virada do ano. O estudo contribui ao analisar uma tradição tipicamente brasileira que tem impacto sobre as vendas no varejo de vestuário e precisa de um melhor entendimento acadêmico. Em termos de gestão, há uma indicação clara do consumo social das roupas e da influência do grupo que pode ser usada nos argumentos de comunicação dos varejistas aos consumidores.

Palavras-chave: influência social, valores, consumo simbólico, véspera de Ano Novo.

\section{INTRODUCTION}

What should I wear? Perhaps that is the doubt that people have in Brazil when thinking about how to dress to a New Year's Eve party. In that time of the year, it is common to observe that the retail stores are prepared to receive the consumer, and, most times, the windows are structured with artifacts that represent that moment of the year, full of symbolic icons related to the syncretism Brazilian culture. The white clothing, for example, is one of the symbols of this period that has a positive meaning such as spiritual peace, new things in the New Year; other than the influence of religious syncretism of Catholicism and African creeds brought to the country by slaves.

The fact that New Year's Eve is a free manifestation and of universal character, people's consumption behaviors, is exposed through the clothes they wear in social parties that night. That occurs because individuals have the necessity of socialization due to their nature. In the social environment, they usually are part of groups and attempt to please others, following indications of how to behave from the observation of those around them (COHEN; GOLDEN, 1971; COSKAN, 2010). The desire that some people have to adjust or identify themselves with individuals or groups is the first motivation to many of their purchases and activities. There are those who do everything to please the members of a group whose acceptance interests them (COHEN; GOLDEN, 1971; BURNKRANT; COUSINEAU, 1975), both because of the self-presentation concerns and for fear of negative evaluations (ROBERTS; MANOLIS; PULLIG, 2014).

According to Belk (1988), possession of goods and services may represent the extended self of an individual. This author adds that the comprehension of consumer behavior requires the understanding of the meaning people attribute to the possessions. In this study, the interest lies in possession of white clothing in a particular special date: the last day of the year, as a sign of peace and positive energy for the year to come, when individual performs rituals full of symbolic meaning. Furthermore, in the Brazilian context, there is a particular social judgment, both positive and negative, depending on the religion and its practices, on wearing white on that day (especially when it is associated with afro Brazilian religions). In addition to that, it is questioned whether personal values and the interpretation of information from other people's social judgment may explain, somehow, the act of dressing in white, something thus far not investigated in the literature. This is our theoretical gap. After reviewing the literature, and considering the 
specific Brazilian cultural context, we believe we can enrich the literature with a unique consumer cultural context, and how this impact apparel sales to be worn in New Year eve celebration.

Despite author's effort to try to find studies analyzing the influence of values and social judgment on the adherence of fashion products associated with customs and culture, it is understood that these characteristics strongly observed in the Brazilian culture. It constitutes a specific reality; which requires an investigation that is relevant both to the knowledge of consumer behavior (consumer culture) and to the practices of the fashion retail market. Empirically it is possible to observe that in December, clothing store windows are 'dressed in white.' We believe that understanding this phenomenon it is relevant for the development of actions that can better activate individuals for consumption, on the retailer side, taking into account the meanings of clothing colors and Social representativeness.

Hereupon, this article purpose is to verify how the individual interpretation of social influence from social groups relates to symbolical consumption of white clothing in the New Year's Eve festivities.

The motivation for this research is twofold: first, being Brazilians, the authors have experienced themselves the process of buying and wearing brand new white clothes during New Year's Eve celebration. Also, family members and friends tend to follow this tradition, this way, a personal interest in the theme to be scientifically investigated after a theoretical gap was found, it was our first motivation. Secondly, empirically, we have observed that during December, apparel store windows portrait white clothes all over Brazil, offering different options for consumers that want to follow this cultural tradition. So, we believe that our finds can also help retailers to understand better and take advantage of the knowledge here presented, to reinforce this tradition and take advantage on increasing sale numbers in the month of December.

Having presented the research goal, it follows with the review of the literature over the thematic and method of investigation used. Later, the analysis and discussions are described, ending with conclusion and references used for theoretical articulation.

\section{INFLUENCES AND SOCIAL COMPARISON OF THE CONSUMER}

The emotions, thoughts, and motives of an individual, act as forces to put to motion the psychological activities of others. All social relations - cooperation, suspicion, and aversion - and all combined actions, such as collective festivities, are the product of the interaction. In addition to that, all subsequent relations between groups or between a person and a group, are based on the primary events that occur between one person and another (ASCH, 1977). Griskevicius and Cialdini (2010) consider social life to be one of the most critical prerequisites for human survival and their main rules include, at least, cooperation and coordination. Those simple prerequisites also reveal that, for being evolved, people can influence and be influenced by others. With that, they define social influence as the manner in which people are affected by real and imaginary pressure from others. The process of influence occurs when an individual's attitudes, cognitions and behaviors are altered by the influence of another individual or reference group (GRISKEVICIUS; CIALDINI, 2010; HSU; LIN, 2016).

The most subtle ways to modify thoughts and behaviors of others during the social interactions have been the object of empirical works and the development of the theory in the scientific study of social influence (COHEN; GOLDEN, 1971; ROBERTS; MANOLIS; PULLIG, 2014). As reported by Sherif (1936 apud Coskan, 2010), people use the behavior of others to establish possible behaviors standards (as a reference scheme). That mere tendency is sufficient to the creation of norms and a consensus in groups of people. 
In the literature of consumer behavior, it is notorious the influence of groups over the individual behaviors, especially of the reference groups, which, according to Solomon (2013, p. 406) are related "to the individual or groups that are significantly relevant in the evaluations, aspirations or individual behavior." That influence leads the individual to pay attention to the behavior of others and to self-monitor in situations of socially visible consumption.

Lennox and Wolfe (1984) indicate that people who adopt the self-monitoring stance have two distinct objectives, one is regarding the management of their presentation, in order to obtain power or status, and the other is a way to avoid social disapproval, the "belonging". The individual is mainly concerned with what other people think of about him, and in what others wear and purchase; aspects that influence their decisions when purchasing goods or services.

In this articles' context, it is known that the year-end festivities are celebrated with friends and/or family, where there is group interaction. The "normal" behavior is to be accompanied by others during that period. It is possible to exist, a greater concern with the information coming from social judgment. That positioning reinforces the importance of investigating how far the choice of clothes and/or color of clothing items in rituals of New Year's Eve celebrations are influenced more by individual values or by the information of social judgment captured by the individual. A rather peculiar aspect of Brazilian culture, the tradition or superstition of wearing white at the new year's eve, heats retail and the storefronts throughout the country exhibit white garments of different designs and prices that cater to different social classes. Thereby, there is an opportunity for research with potential theoretical and practical implications in this context.

\section{PERSONAL VALUES}

Human values are personal characteristics composed of elements originated from the cultural, behavioral and emotional features of the individual. Personal values may vary between people with the same cultural characteristics or even raise by the same family, however, they transcend situations or events and are more durable for being more central in the personality structure (BLACKWELL; MINIARD; ENGEL, 2005). According to Schwartz (1996), values represent three universal requirements of human existence: biological necessities, the requirement of coordinated social interactions and demands for the survival and functioning of the group (SCHWARTS, 1996; BURGESS; STEENKAMP, 1998).

Consumers frequently modify their behavior regarding consumption, and their preferences and choices may vary according to their values. That is, values guide consumer behavior and influence decision making (ZASUWA, 2016, SHARMA, JHA, 2017). Even in corporate markets, where the products and services are allegedly more homogeneous, consumers express diversified preferences and a less predictable buying behavior than assumed; especially when they care about the comparison in groups (KAHLE; KENNEDY, 1989).

Value is a belief that guides actions and judgments employing goals and specific occasions, other than the immediate goals for deeper final states of existence. When internalized, consciously or not, they become a pattern of criteria that guides human action developing and sustaining attitudes towards objects and situations, in order to justify personal and others' motivations, judge oneself and the others morally, to make comparisons to others and try to influence the others. People use the values learned culturally to create and utilize conditions of morality and competence, to provide social interaction and support the rationalization of behavior, attitudes, and beliefs where those values would be hierarchically structured composing an individual's system of values (ROKEACH, 1968; KAHLE; KENNEDY, 1989). Recent research is based on these 
ideas (PISCICELLI; COOPER; FISHER, 2015; ABDOLLAH; ABDULLAH; VOON, 2016). Accordingly, it is believed that the understanding and identification of personal values of a group of individuals are relevant to understand aspects regarding social comparison and symbolic consumption.

\section{SYMBOLIC CONSUMPTION}

Consumption has two great perspectives, utilitarian and symbolic (FERLA; SILVEIRA, 2008; LUNA-CORTES (2017). The first considers the utilitarian character and commercial value of products, as the second one believes that consumption goods have significance beyond such attributes (McCRAKEN, 2007). When purchasing a product, one also considers its symbolic attributes. In other words, what it represents to him and for others of the social or reference group. The consumer perceives, in this dimension, the benefit of the product as a symbol, as a representation of something to himself and/or to others (RUCKER; GALINSKY, 2008).

The symbolic aspects of consumption have raised greater interest in scholars of consumer behavior around the 50's, after the seminal article 'Symbols for sale' - by Sidney Levy, considered a pioneer in reinforcing the importance of symbolism in consumption (MICK, 1986). To Levy (1959) the consumer ceased to be economical and rational to become 'uneconomical', and as well as consider the traditional values of products and services such as price, quality, and durability, began to recognize that other elements affect and influence their choices, of emotional and aesthetic character, with a substantial symbolic burden, that sometimes becomes an extension of self.

Corroborating this idea, Schmitt (1999) considers consumer to be a rational and emotional human being, increasingly interested in performing pleasurable experiences, for a while that makes rational choices, is driven by emotional factors (SCHMITT, 1999). The subjective experience transmitted by consumption contributes substantially to the structuring of the consumer's social reality, their self-concept, and behavior (SOLOMON, 1983). The referred author observes that consumer often depends on social significance inherent to products as a guide to performing their social parts, especially when these are new.

The symbolic character consumption offers an individual the opportunity to build, maintain and communicate social identity and meanings (ELLIOT, 1997). This is because the relationship between consumers and objects or events occur based on the symbolic meaning given by society, the purchase of a given product may occur not for its essential functions, but by what it represents and means to the individual (LEVY, 1959; LEIGH; GABEL, 1992). Elliot (1997) emphasizes that the individual is an active agent in the construction of meanings. In that context, it must also be considered that the meanings attributed to products are a social construction, and in that process, the individual may concern, at a greater or lesser intensity, with the social judgment in the purchase and use of goods, due to the symbolic burden it is associated with.

\section{THE MEANING OF THE USE OF WHITE CLOTHING IN NEW YEAR'S EVE, COLORS AND SUPERSTITIONS}

The New Year is characterized for being a ritual full of symbolisms (ROOK, 1985; PETTIGREW; RYAN; OGILVIE, 2001) and marked by traditions, beliefs, customs, and superstitions. The ritual is considered an "expressive and symbolic sort of activity built by multiple behaviors that occur in a steady and episodic sequence and that tends to repeat itself over time" (ROOK, 1985, 
p.252). According to the author, this definition interprets the ritual as a positive and significant aspect, both in everyday human experience, as in the extraordinary. Superstitions, on the other hand, are beliefs that contrary rational thought, they may have personal or cultural nature and are performed to bring good fortune or to repel bad luck (BLOCK; KRAMER, 2009).

The ritual, to Rook (1985), is based in four components: artifacts, script, exercised part, and audience. The artifacts, when utilized in a ritualistic context, frequently communicate specific symbolic messages that are essential to the meaning of the experience as a whole. Clothing artifacts, for example, convey different meanings to both consumers and observers. Some meanings may be broadly shared by the group, while others may be inherent in the individual's identity (MILLAN, REYNOLDS, 2014). The script identifies not only the artifacts to be used but its behavioral sequence and by whom they shall be used. The exercised part corresponds to the individual's functions in the ritual, and the audience involves the greater public to whom the ritual may be destined to. The New Year's ritual can be celebrated with a series of artifacts, such as fireworks, confetti poppers, and champagne, leading to the familiar countdown to New Year's Eve (ROOK, 1985). However, that ritual is characterized for having a certain degree of uncertainty about the script and representation of parts, since it may be performed at home or in a public venue, and some people may choose not to participate in the New Year's Eve festivities, but to celebrate the following day with close friends and family (ROOK, 1985). Despite the alluded evolution of customs and popular culture, and the rational emphasis of post-industrialized cultures, people still tend to believe in superstitions and often appear to be strongly motivated by its practices. That occurs because, as an example, Christmas, New Year's Eve and Epiphany are the fundamental dates of the Christmas Cycle, and they have been, according to Debret (1949), festive occasions marked by the exchange of gifts (mainly edible), the renewal of the slaves clothing and the distribution of donations to the subordinates. The exchange of gifts and traditional food are still frequent in these festive periods.

When it comes to superstition, since the turn of the year is an event that marks the entrance of a new life, people have similar and distinct beliefs to that moment (ROOK, 1985). Those who are more superstitious tend to believe that adding things that are not common to their daily lives might bring positive energy, and make possible the accomplishment of dreams in the year to come. Superstitious and symbolic rituals are usually associated with food (for example, to consume lentils, pomegranate, grape berries, pork meat, nuts, hazelnuts, chestnuts and dates), apparel (new intimate apparel, white clothing - which in Brazil, is a relatively recent habit, established after the popularization of African religions, representing light, world peace, purity, kindness - yellow clothing items, money inside the shoes, among others) and, at midnight, rituals such as throw coins inside the house, jumping seven waves at the sea, among others, are practices performed by many people.

Although white prevails, other colors have been suggested and worn in that period, each one with a unique meaning, and so people may wear several colors on the occasion. These colors and their meanings in apparel are considered relevant in this festive period, and they are part of the imaginary and culture the authors live. One learns in the socialization process the assigned meanings that can vary from one location to another. In the social context of the authors of this article, these are the representations of colors in the festivities of the holiday season.

\section{METHODOLOGICAL PROCEDURES}

The research developed in this study has assumed a stance of quantitative and qualitative nature. Authors believed this approach would enrich the understanding of the phenomenon 
and reduce the bias of an exclusively quantitative or qualitative approach. Both methods are recommended to understand the recent phenomenon, explore opinions, behaviors, and attributes (MORGAN; SMIRCICH, 1980; GODOY, 1995), primarily when they are used together.

On that basis, it was first held personal interviews with a semi-structured script, with questions pre-established by the researchers, along with ten informants. The saturation criterion was adopted to established the number of interviews to be performed. Close to the $8^{\text {th }}$ interview, we realized that the comments of the informants did not bring new perspectives to the topic, and this way, we finished the interview process when we achieved the $10^{\text {th }}$ respondent. The average length of the interviews was about 55 minutes. In the script, there were questions about: the usage of white on New Year's Eve, the meaning of white to the occasion and/or if other colors are used, it the clothes should be new if the informant had any superstitious practice and items of identification and demographic characteristics. To choose the informants, it was considered accessibility, as well as some criteria the researchers found relevant, such as religion, gender (so there would not be a concentration of people of only one religion or same gender). The filter to participate in the interview was to have celebrated the New Year's Eve of 2013 to 2014, with that stage begun in early January 2014. The authors held the interview themselves.

For the implementation of the survey it was used a structured questionnaire composed of three blocks: the first one measured the social influence of the consumer from their attention to social comparison, based on the scale "Attention to Social Comparison Information" (ATSCI), proposed by Lennox and Wolfe (1984). The second block measured the personal values of the individuals from the "List of Values" (LOV) of Kahle (1983), and the third block had the respondents' demographic items. It was also included a question regarding the use of white clothes in the holiday season. The scales translation was done by a researcher with knowledge of the English language, and later, another professor with English proficiency did the reverse translation from Portuguese to English. There was no compromising discrepancy in the meaning of the words and sentences, and so, the questionnaire was ready to be applied. The questionnaire was pre-tested along to a group of ten respondents, with no adjustments needs before we started the survey.

For the data collection two strategies were used: attendance application by the researcher with students of a public university and by the internet, using of "Survey Monkey", with a link in the researchers' social network, inviting their friends to participate in the survey, as well as soliciting its divulgation in a "snowball" type strategy. Thereby, the universe of respondents here considered comprehended all the people who like and somehow celebrate New Year's Eve. The investigated target audience had the following characteristic: people with a habit of celebrating New Year's Eve, of both genders, with age equal or superior to 18 years old. Following parameters for sample definition, according to Hair, et al. (2006) and Malhorta (2006), for the use of varied and multivariate analysis, minimal sample of 50 respondents is needed. Thus, given this parameter, 176 questionnaires were collected in January 2014, however, in the data treatment phase, it was verified that 12 formularies should be excluded from the analysis, remaining then, 164 valid for the statistical treatment, adequate amount for the kind of statistical analysis applied to the data. From that total, 69 were collected in person and 95 by the internet. We did not find any significant difference between the two means of data collection.

For the analysis of qualitative data, we performed the transcription and used thematic analysis that consists in discovering the centers of sense which compose the interviewees' speech. 
This technique privileges the content of the reports, these being confronted with theory. For a better apprehension and posterior analysis of data, it has been made a pre-analysis, the exploration of the material and treatment of the results and interpretation (BARDIN, 2006). Since the results present exploratory characteristics, and the analysis evidenced the content, it has been considered that results could generate only hypothesis and not definitive conclusions to complete the survey.

For the analysis of quantitative data, the adopted procedures to prepare the data were adherence and reliability tests. There were also performed normality tests and calculating the Cronbach's Alpha (AAKER; KUMAR; DAY, 2001). The results were generated from descriptive statistics, correlations, and logistic regression templates. The goal of logistic regression was to find the best relationship between the response variable (dependent) and a group of predictive variables (independent), is the final template the one with the best mathematical adjustment, and the most appropriate variables to explain the phenomenon (HOSMER; LEMESHOW, 200). For the evaluation of validity, it was performed a theoretical confrontation with the findings, seeking to identify the convergent or divergent validity from what other results indicate (COOPER; SCHINDLER, 2003), in both collection procedure.

\section{RESULTS AND ANALYSIS}

The results and analysis of the qualitative and quantitative stages will be presented in a group, according to their characteristics, to perform confrontations between the findings and the theory analyzed in a unified manner, without defined order of presentation.

Out of ten informants interviewed, five are male gender, and five are female gender. Ages range from 25 and 49 years old. Three are attending college, three concluded, and four are post-graduated (specialization and master degrees). Concerning religion, five are Catholics, two are of Candomblé, one evangelical, one spiritualist and one agnostic, also having a family income at a monthly average of $\mathrm{R} \$ 6.000,00$.

\subsection{Analysis of Sample Distribution, Correlation, and Factors}

According to data of Table 1, the item of greatest accordance among the participants was 'V4: When I am not sure how to behave in a social situation, I observe the behavior of others as clues to such' $(\mu=4,05)$. In another extreme, the item with the lowest average agreement $(\mu$ $=2,23)$ and higher standard deviation $(\alpha=1,271)$ was ' $V 1$ : If everyone in a group behaves in a certain way, I feel that this must be the appropriate way to behave'. Although the highest level of responses from the participants has indicated that in case of doubts about the way to behave in a social situation they try to get clues from the behavior of others, there was low agreement regarding how to behave from the way in which a group behaves. 
Table 1: Descriptive analysis of the construct consumer social influence and personal values

\begin{tabular}{|c|c|c|c|}
\hline Consumer Social Influence & Ave. & sd. & K. \\
\hline $\begin{array}{l}\text { V1: If everyone in a group behaves in a certain way, I feel that this must be the ap- } \\
\text { propriate way to behave }\end{array}$ & 2,2 & 1,27 & $-1,16$ \\
\hline V2: I avoid wearing clothes that are not trendy & 2,5 & 1,18 & $-0,98$ \\
\hline V3: At parties, I usually try to behave in a way in which i fit in the context & 3,4 & 1,18 & $-0,45$ \\
\hline $\begin{array}{l}\text { V4: When I am not sure how to behave in a social situation, I observe the behavior } \\
\text { of others as clues to such }\end{array}$ & 4,0 & 0,99 & 1,83 \\
\hline $\begin{array}{l}\text { V5: I try to pay attention to other people's relationship with my behavior, with the } \\
\text { purpose to avoid being out of place }\end{array}$ & 3,4 & 1,16 & $-0,49$ \\
\hline $\begin{array}{l}\text { V6: When i am somewhere, i take other people's slangs and incorporate them as } \\
\text { part of my vocabulary. }\end{array}$ & 2,8 & 1,41 & $-1,44$ \\
\hline $\begin{array}{l}\text { V7: The slightest disapproval look in the eyes of the person I am interacting with is } \\
\text { enough to make me change my }\end{array}$ & 2,8 & 1,35 & $-1,41$ \\
\hline V8: It is important to me that I fit in the group I belong & 3,5 & 1,18 & $-0,38$ \\
\hline V9: My behavior often depends on how I feel that others wanted to me to behave & 2,2 & 1,15 & $-0,99$ \\
\hline $\begin{array}{l}\text { V10: If I am not sure of how to behave in any social situation, I observe the behavior } \\
\text { of others looking for clues to such }\end{array}$ & 3,7 & 1,09 & 0,91 \\
\hline $\begin{array}{l}\text { V11: I usually keep myself updated to changes in clothing styles, checking what } \\
\text { others wear }\end{array}$ & 2,9 & 1,28 & $-1,10$ \\
\hline $\begin{array}{l}\text { V12: When facing a social situation, I try not to follow the crowd, but instead I be- } \\
\text { have in a way that is suitable to my mood at that moment }\end{array}$ & 3,9 & 1,01 & $-0,00$ \\
\hline
\end{tabular}

Ave = average; $\mathrm{sd}$. = standard deviation; $\mathrm{n}=164 ;$ adapted scale of 1 to $5 ;(\mathrm{R})=$ reverse; $\mathrm{K}=$ Kurtosis

Table 2 represents the degree of importance the research participants attributed to each value in the LOV list. Although the data represent strong positive inclination in the answers, the values that received higher frequency of total accordance were 'sense of accomplishing' with $79,3 \%$ self-realization with $75 \%$, distributed to all ages. However, people older than 50 years old also demonstrated to appreciate 'security' and 'self-respect'.

Table 2: Descriptive analysis of the personal value construct

\begin{tabular}{|c|c|c|c|}
\hline Personal Values & Ave. & sd. & K \\
\hline V13: Sense of belonging & 3,5 & 0,98 & $-0,06$ \\
\hline V14: Excitement & 3,5 & 0,95 & $-0,05$ \\
\hline V15: Warm relationships with others & 3,9 & 0,94 & 0,59 \\
\hline V16: Self-realization & 4,6 & 0,69 & 8,73 \\
\hline V17: Being well respected & 4,5 & 0,66 & 4,51 \\
\hline V18: Fun and pleasure & 4,4 & 0,78 & 1,89 \\
\hline V19: Security & 4,4 & 0,84 & 3,05 \\
\hline V20:Self-respect & 4,6 & 0,67 & 2,29 \\
\hline V21: Sense of accomplishment & 4,7 & 0,55 & 13,02 \\
\hline
\end{tabular}

Next, it was evaluated the matrix correlation of the two scales used. For being non-metrical, the Sperman coefficient was used to correlation. That measure uses classifications instead of the absolute values that range from $-1,0$ to $+1,0$ (MALHOTRA, 2006). The matrix showed adequate correlation but does not show very high values of correlation, which did not indicate collinearity problems, for both the scales analyzed. For a better understanding of the behavior of the scales used, aiming to guarantee the reliability of data, it was calculated Cronbach alpha coefficients, which measures internal consistency of multiple scales (MALHOTRA, 2006; HAIR et. Al., 2006). The result was satisfactory, indicating high internal consistency for consumer social influence scale $(\alpha=$ 
$0,706)$ and personal values $(\alpha=0,725)$. With the adaption made in the scale, became $0-5$ to Likert 5 points, where 1 had a minimal disagreement and 5 maximum agreement with a neutral point (3). In that form of measurement the respondent must classify objects in function of some mutual variable, and the use of categorization allows to obtain an almost-range scale, allowing an approximation of the ideal interval form for multivariate statistical calculations (AAKER; KUMAR; DAY, 2001); In the same way adaptation of the LOV scale was made, that of 9 points in the original scale (KAHLE; KENNEDY, 1989) adapted to 5 points. The results align themselves to the ones found in the original Lennox and Wolfe (1984) scale, that presented $\alpha=0,77$ coefficient.

In the first round of analysis the variable 'V12: When facing a social situation, I try not to follow the crowd, but instead I behave in a way that is suitable to my mood at that moment' presents load 0.171 , which is deleted. Next, after a new round, results were adjusted. The original Lennox and Wolfe (1984) scale groups the variables in three dimensions, remaining, in the final version, two dimensions named "capacity to modify self-presentation' and 'sensitivity to expressive behavior of others'. However, considering the scale was adapted to the recent study, in the exploratory factorial analysis held, were identified four factors that received denominations aligned to Lennox and Wolfe (1984) original study and the analyzed object (see pages 1357 and 1361 respectively).

The calculation of the KMO test resulted in 0,778 , demonstrating good adaptation of variables to the method. In Bartlett's sphericity test, the result was 410.014 with 66 degrees of freedom and a significance level of $p<0.0000$. Thereby, the test results confirmed the possibility of utilization of this method for data treatment. In the analysis of the eigenvalues, it is observed that these are presented in decreasing order, from component 1 to 12 . Factor 1 accounts for 16.8 $\%$ of the variance, Factor 2, of 16, $7 \%$, Factor 3, by 13, $9 \%$ and Factor 4 by $13,6 \%$ of the total variance. In accumulated variance, the four factors combined correspond to $61,0 \%$ of the total variance, indicating to be recommended the extraction of four factors of the analysis. According to Malhotra (2006), it is recommended that extracted factors represent a minimum of $60 \%$ of the variance.

Table 3: Loading factors (exploratory) of the consumer social influence scale

\begin{tabular}{|c|c|}
\hline Fear of negative evaluation & F1 \\
\hline $\begin{array}{l}\text { V1: If everyone in a group behaves in a certain way, I feel that this must be the appropriate way } \\
\text { to behave }\end{array}$ & 0,680 \\
\hline V3: At parties, I usually try to behave in a way in which i fit in the context & 0,585 \\
\hline $\begin{array}{l}\text { V5: I try to pay attention to other people's relationship with my behavior, with the purpose to } \\
\text { avoid being out of place }\end{array}$ & 0,502 \\
\hline V8: It is important to me that I fit in the group I belong & 0,533 \\
\hline Sensitivity to expressive behavior of others & $\mathbf{F 2}$ \\
\hline $\begin{array}{l}\text { V4: When I am not sure how to behave in a social situation, I observe the behavior of others as } \\
\text { clues to such }\end{array}$ & 0,852 \\
\hline $\begin{array}{l}\text { V10: If I am not sure of how to behave in any social situation, I observe the behavior of others } \\
\text { looking for clues to such }\end{array}$ & 0,855 \\
\hline Capacity to modify self-presentation & F3 \\
\hline $\begin{array}{l}\text { V6: When I am somewhere, i take other people's slangs and incorporate them as part of my vo- } \\
\text { cabulary. }\end{array}$ & 0,600 \\
\hline $\begin{array}{l}\text { V7: The slightest disapproval look in the eyes of the person I am interacting with is enough to make } \\
\text { me change my }\end{array}$ & 0,714 \\
\hline V9: My behavior often depends on how I feel that others wanted to me to behave & 0,686 \\
\hline Sensitivity to Fashion Trends & F4 \\
\hline V2: I avoid wearing clothes that are not trendy & 0,795 \\
\hline V11: I usually keep myself updated to changes in clothing styles, checking what others wear & 0,833 \\
\hline
\end{tabular}


Following, the factor analysis of the scale of values was applied. In the first round, the scale was divided into two factors. Adjustments and exclusions of low charge $(<0,50)$, variables were made. The variables that presented charges and values adequate for the construct utilization were: 'self-realization' $(0,774)$, 'being well respected' $(0,786)$, 'security' $(0,725)$. 'self-respect' $(0,617)$ and 'sense of accomplishment' $(0,721)$. The calculus of the KMO test resulted in 0,779 , demonstrating good adequacy of variables to the application of the method. In Barlett's sphericity test, the result was 207,024 with ten degrees of liberty and significance level $p<0,0000$. The factor corresponds to $62,5 \%$ of the total variance. This way, the tests results also confirmed the possibility of utilization of that method for data treatment. Although the grouping of variables was made, some analysis was held considering all values (KAHLE; KENNEDY, 1989).

\subsection{Analysis of Interviews and Statistic Relation}

\subsubsection{Qualitative analysis}

In qualitative analysis, it was verified that the use of white is more related to tradition and religious aspects. Some participants who wear it, consider that wearing white clothing during that period is a pleasant custom and makes them feel good. Others believe it to be a commitment with yourself and others, since white means world peace, tranquility, and transparency. The informant (19) indicates that he wears it because everyone else wears it:

"everyone wears it, it' a social convention and a tradition among my family members. When we are together, wearing the same color, in that case, white, I feel union. Perhaps with another color I could not feel part of my family in that special moment. For that reason I prefer to wear white [...] It is good to feel part of the group, especially friends and family". One of the informants (17) who is of Candomblé, affirmed "I usually wear for believing the color of the clothes have a meaning for the starting year [...] I do not feel any social obligation. I have changed the year with several other colors. However, I have a special affection to white for being the color of Oxalá, my protector Orisha, which is why I wear it.

The informant (12) affirmed: "I wear it ... more out of tradition. Everyone wears white, I find it an interesting tradition, beautiful". In that, and in the other considerations, it is possible to observe the characteristics of social identification by means of groups, that on an account of a custom that comes from tradition or religious belief. But, for those who don't wear white, other colors such as yellow, red, pink, green or blue have other meanings and can be a form of differentiation. The informant (I10) considers: "I have worn white clothing a lot, and to me it represents peace. But, sometimes, I feel I want to be different by wearing other colors. In the last New Year's Eve, for example, I wore blue and red... I was the only one wearing those colors in my house. I though I was out of standards, but it was nice... I liked being the different one [laughter]". Those descriptions are in line with the Mehta and Belk (1991) considerations. To the authors, in the process of identification with a group, the individual may opt by the differentiation dimensions (symbolizing himself) and integration (symbolizing others), as the case of people who use white by tradition and social convention.

Regarding religion, the participants who are of Candomble and the spiritualists indicated that beyond following tradition, they sometimes wear it because of the religion. But, they do not consider it to be an obligation, only an identification of pairs and religious rituals that exist. On the other hand, even with not much expressiveness in the use of white, eight of them indicated that they like to spend New Year's Eve with new clothing, by the fact that it represents new life for the coming year, with colors the as varied as possible. Usually, the colors vary with the type 
of item, as emphasizes the informant (14): "Yes, it has to be new. Yellow panties and red or pink bra". As to the rituals, the most representative were: play and fun (without believing much in the meaning of it), spend it at the beach with champagne (that beverage representing love, abundance and happiness), grapes, pomegranate, rice, and flowers. The informant (18) comments: "at the end of the year, may not be absent grapes and flowers for my ritual along with family and friends. They all follow this ritual. That makes me light for the New Year". It can be considered that the rituals are representative to people during the festivities period, being held in the most diverse manners, with collective and individual formats, however, these are not directly related to the white color. Briefly, the analysis revealed the following thematic for the use of white clothes: the religious matter, aspects of fun and of following the group.

\subsubsection{Quantitative analysis}

In this stage, some analysis strategies were structured with the intention to find relationships between the variables and the behavior of wearing white clothes in the festivities at the end of the year. Firstly, were conducted some tests of difference of average considering groups of people who wear and who do not wear white clothes about demographic variables. This way, from the $U$ test of Mann-Whitney, it was verified that there are no valid results to affirm that there is response difference to groups of people who wear and who do not wear white regarding sex, age, income, and education. In other words, it did not have statistical significance to the analysis. On the other hand, it was possible to observe that the women who indicated a high monthly family income (classified as A and B), tend to wear less white clothes (18\%) compared to men $(13 \%)$ in the same situation. To lower incomes (C, D, and E) it was not possible to find any relation.

It was chosen the utilization of logistic regression method to estimate probabilities concerning classes of monthly family income, as well as other demographic variables. After the sample distribution analysis, correlation and identification of the factors, it was preceded with the construction of the logistic regression template. Several simulations of probabilistic templates were tested, and in each simulation, it was conducted the Hosmer and Lemeshow (2000) test. The tests indicted the possibility of performing logistic regression in three templates. The dependent variable that indicates if the participant 'wear white clothes in new year festivities' was analyzed regarding the demographic variables (Template 1), values (Template 2 ) and extracted latent dimensions of scale attention to social comparison (Template 3 ).

After completed the simulations for Template 1, the dependent variable ('wear white clothes in new year festivities') showed predictive power regarding the variable economical class (sig. 0,009), excluding the variables gender, religion, and education. As a result, the esteemed random template is:

$$
\log \left(\frac{P}{1-P}\right)=\beta_{0}+\beta_{1} \text { Economical Class }
$$

Table 4: Template of the probability of use of White apparel and demographic variables

\begin{tabular}{ccccccc}
\hline Demographic variables & B & S.E. & Wald & df & Sig. & Exp(B) \\
\hline Economical Class & $-0,463$ & 0,178 & 6,751 & 1 & 0,009 & 0,629 \\
Constant & 0,858 & 0,718 & 1,430 & 1 & 0,232 & 2,359 \\
\hline
\end{tabular}

With this, in this first probabilistic model, the variable statistically relevant to esteem the probability of use of White clothes was 'economic classes, esteemed based on family income. The 
second column of Table $4(\beta)$ corresponds to the parameters and values of coefficients, which will form the logistic template. Therefore, excluding other variables, the template was presented as:

$$
\log \left(\frac{P}{1-P}\right)=0,858+(-0,463) \text { Economical class }
$$

The fact that the constant $\beta_{0}$ appeared as positive indicates that in the studied group, especially to those who present more elevated Family income, it is possible to affirm that there is a higher probability of wearing White clothing in the New Year's Eve festivities. The overall percentage of correct classification of the template has reached $63,2 \%$ indicating that it is considered satisfactory for performing future forecasts. As for the odds ratio, the 'economical classes' variable, highlighted in the previous template, indicates that the higher the economical class (in this case esteemed by monthly family income) the individual belongs to, higher the probability of wearing white clothes in new year's festivities, enhancing chances of use 0,629 times, especially when they feel the necessity to be part of a group. For example, to those who don't wear it, as their income increases, so does the probability that they will start to. But, that does not characterize that the ones who wear it the most are the ones with higher income.

In Template 2, two variables of the values scale presented greater predictive power, being estimated the second template for the probability of use of White clothes in New Year's festivities. Therefore, the estimated template used as independent the variables "warm relations with others' (sig. 0,015) and 'fun and pleasure' (sig. 0,021). As result, the esteemed random model is:

$$
\log \left(\frac{P}{1-P}\right)=\beta_{0}+\beta_{1} \text { WarmRelations }+\beta_{2} \text { FunPleasure }
$$

Table 5: Template of the probability of use of White clothing regarding personal values

\begin{tabular}{ccccccc}
\hline Personal Values & B & S.E. & Wald & df & Sig. & Exp(B) \\
\hline Warm relations with others & 0,538 & 0,221 & 5,937 & 1 & 0,015 & 1,712 \\
Fun and Pleasure & 0,658 & 0,285 & 5,329 & 1 & 0,021 & 1,930 \\
Constant & $-7,044$ & 2,341 & 9,059 & 1 & 0,003 & 0,001 \\
\hline
\end{tabular}

In the same manner, the second column on Table $5(\beta)$ corresponds to the parameter or values of the logistic coefficients, which formed the logistic template. Therefore, excluding other variables, the template was presented as:

$$
\log \left(\frac{P}{1-P}\right)=-7,044+0,538 \text { WarmRelations }+0,658 \text { FunPleasure }
$$

Unlike Template 1 , the fact that constant $\beta_{0}$ was presented as negative, means that there is la ow probability of wearing White clothes in the New Year's festivities when considering the individuals" personal values. Overall percentage of correct classification of template has reached $66,5 \%$ indicating it is considered satisfactory for performing future forecasts. As for the odds ratio, variables 'warm relations with others' and 'fun and pleasure', highlighted in the Template, indicate that the more individuals appreciate warm relations with others, as well as fun and pleasure for their lives, the more likely it will be that they wear White clothing for the New Year's festivities, increasing the chances of use 1,712 and 1,930 times, respectively. In other words, if the use of white clothing favors warm relations with others, fun and pleasure, there will be a high probability those people will wear it. In that case, the use of White clothes for New 
Year's Eve. By analyzing the characteristics of those who gave those values more preference, it was observed that the findings were aligned to the Kahle and Kennedy (1989) descriptions. To the authors, for example, warm relations with others is a value chosen especially by friendly women and has many friends, divorced men, religious and housewives. Fun and pleasure, on the other hand, are chosen by irreverent young people who appreciate life and are focused on pleasure, usually unemployed, starting careers or working with sales. They don't like to live with religious or family rules; they are very optimistic and enjoy sports and leisure.

In Template 3, only one dimension of consumers' social influence presented higher predictive power, is estimated the third Template. Thus, the estimated template used as independent the dimension 'capacity to modify self-presentation' (sig. 0,038). As a result, the random estimated template is: é:

$$
\log \left(\frac{P}{1-P}\right)=\beta_{0}+\beta_{1} \text { CapacModSelf Presentation }
$$

Table 6: Template of the probability of use of White clothing regarding personal values

\begin{tabular}{ccccccc}
\hline Influência social do consumidor & B & S.E. & Wald & df & Sig. & Exp(B) \\
\hline Capacity to modify self-presentation & $-0,425$ & 0,204 & 4,326 & 1 & 0,038 & 0,654 \\
Constant & $-0,392$ & 0,736 & 0,283 & 1 & 0,595 & 0,676 \\
\hline
\end{tabular}

The second column in Table $6(\beta)$ corresponds to the parameters or values of logistic coefficients that formed Template 3 . Therefore, excluding other variables, the template was presented as:

$$
\log \left(\frac{P}{1-P}\right)=-0,392+(-0,425) \text { CapacModSelfPresentation }
$$

The fact that constant $\beta_{0}$ was presented negative, also means there is low probability of use of White clothing by the participants. However, the template is not characterized as irrelevant. The overall percentage of correct classification of template reached 56, $7 \%$ indicating that it is considered satisfactory for performing future forecasts. As for the odds ratio, the variable 'capacity to modify self-presentation' indicates that the greater the capacity from the individual to modify their self-presentation in order to participate of a social group, greater the probability of them wearing white clothes when their group is, increasing chances of use 0,654 times. In other words, the choice of wearing will not be made on account of personal option, but by aspects as characteristics of a group, customs, tradition or even religious reasons.

Literature indicates that the desire some people have to adjust or identify with individuals or group is the first motivation for many of their purchases and activities. There are people who do everything to please the members of a group whose acceptance interests them (COHEN; GOLDEN, 1971; BURNKRANT; COSINEAU, 1975), for self-presentation concerns as well as fear of negative evaluation (ROBERTS; MANOLIS; PULLIG, 2014). Lennox and Wolfe (1984) also considered that people who can modify their self-presentation do so to avoid social disapproval. The individual is mainly concerned with what others think of him and in what others buy and wear, which was possible to confirm with the results of this study. 


\section{CONCLUSION}

This article investigated a phenomenon of Brazilian culture: the use of White clothes in the New Year's Eve festivities. We based our analysis in theories of personal values and influence of social judgment, as well as the symbolic consumption. The goal was the understanding of the phenomenon, with the use of two research approaches: qualitative and quantitative. Motivation came from the authors' personal experiences, which experience in their families and friend groups the 'tradition' of wearing White brand new clothes on New Year's Eve. It is also recognized this is an essential period for apparel retail, where White clothing sales tend to increase, and the Windows of stores in traditional commerce and shopping malls "dress" in White to stimulate and remind consumers of that tradition.

Qualitative analysis revealed that aspects of religion, fun, and following consumption patterns and group behavior are important to people during the festivities., As long as some informants attribute a meaning to the use of white clothes, others use it only for fun and tradition, not making white clothes an indispensable item in the year passage. However, it was also observed that the phenomenon is rich in symbolism and is part of Brazilian culture. From the survey data, most participants do not wear white at the year turn, but those who do, are mostly Catholics or Spiritualists. Other colors are used, normally, being attributed several distinct meanings to each color. On account of color variation, doubts appear at the moment of choice, yet, consumers try to choose something more related to their values and social groups.

It was seen that even though most participants indicated not wearing white clothes, they still maintain different rituals in this festive period, still seeking to adjust to social aspects that renew over time. According to Treise, Woulburg and Otnes (1999), people involve themselves in consumption rituals to mark important transitions and to consolidate their ties with the social world. Something drew our attention: the individuals in more elevated economical classes are more likely to wear white clothes, especially when they feel the necessity to be part of a group. Also, as for the values, it was confirmed that if the use of white clothing favors the warm relations with others, fun, and pleasure, there will be a higher probability those people will wear white at the party. These information can be relevant for the development of strategies directed towards upscale consumers.

About the consumers' social influence, it was observed that the higher the capacity of the individual to modify their self-presentation, to participate of a social group, the greater the probability he/she will use white clothes whenever his/hers group does. That means the choice to use white clothes will not be made on a personal account, but because of aspects related to the characteristics of a group, customs, tradition, or even religious matters. Such discoveries are in accordance with the Works that explore the matter of groups and individual social influence (COHEN; GOLDEN, 1971; BURNKRANT; COSINEAU, 1975; LENNOX; WOLFE, 1984; ROBERTS; MANOLIS; PULLIG, 2014).

At last, authors suggest that studies using photography and that are ethnographic may enrich the understanding of this phenomenon. Accompanying families in the holiday's season, in the apparel purchases, and at the New Year's Eve party, may reveal information that was not captured here. In terms of management, there is a clear indication of the social consumption of the clothes, and of group influence, which can be used in communications arguments from retailers to consumers. It is valid to emphasize that other colors represent different meanings to the consumer and that can be explored by retailers in this period, associated with both personal values and individual social relationships with the meanings of each color in a specific clothing collection. There are certain limitations related to the methodological choices here made, as the 
number of participants in the survey, the adaption of the scales, as well as the thematic analysis of content. Yet, it is believed that the theoretical basis applied, the care in the procedure, the precision of regression templates, and systematization in research conduction allow the results to be academically valid and stimulate the achievement of studies with the use of methodological procedures to amplify knowledge in the theoretic field.

\section{REFERENCES}

AAKER, D. A.; KUMAR, V.; DAY, G. S. Pesquisa de marketing. São Paulo: Atlas, 2001.

ABDOLLAH, I. I.; ABDULLAH, F.; VOON, B. H. Developing Scales for Measuring Cultural Values in the Context of Consumer Research. Procedia-Social and Behavioral Sciences, v. 224, p. 421-428, 2016.

ASCH, S. E. Psicologia social. 4. ed. São Paulo: Editora Nacional, 1977.

BARDIN, L. Análise de conteúdo. Lisboa: Edições 70, 2006.

BELK, R. W. Possessions and the extended self. Jornal of Consumer Research, v. 15, Sep., p. 139168, 1988.

BLOCK, L.; KRAMER, T. The effect of superstitious beliefs on performance expectations. Journal of the Academy of Marketing Science, v. 37, n. 2, 2009.

BURNKRANT, R. E.; COUSINEAU, A. Informational and normative social influence in buyer behavior. Journal of Consumer Research, v.2, dec., p. 206-215, 1975.

COHEN, J. B.; GOLDEN, E. Informational social influence and product evaluation. Faculty Working Papers, University of Illinois, 1971.

COOPER, D. R.; SCHINDLER, P. Métodos de pesquisa em administração. 10 ed. Porto Alegre: Bookman, 2003.

COSKAN, C. The effects of self-control and social influence on academic dishonesty: an experimental and correlational investigation. Dissertation, M. E. Tec. University, 2010.

DEBRET, J. B. Viagem pitoresca e histórica ao Brasil. São Paulo: Martins, 1949.

DENZIN, N. K. The research act: a theoretical introduction to sociological methods. 2. ed. New York, McGraw-Hill Book Company, 1978.

FERLA, D. A.; SILVEIRA, T. A relação entre os benefícios simbólicos do consumo e a formação da identidade dos jovens consumidores através de uma abordagem metodológica mista. In: EMA Encontro de marketing da ANPAD, 2008, Curitiba, Paraná: 2008.

GODOY, A. S. Introdução à pesquisa qualitativa e suas possibilidades. Revista de Administração de Empresas, v.35, n.2, p.57-63, 1995.

GRISKEVICIUS, V.; CIALDINI, R. B. Social influence. In R. Bagozzi (Ed.) International Encyclopedia of Marketing, volume on Consumer Behavior, Wiley, 2011. HOLBROOK, M.; HIRSCHMAN, E. The experiential aspects of consumption: Consumer fantasies, feelings, and fun. Journal of Consumer Research, v. 9, no 2, 1982. 
HOSMER, D. W.; LEMESHOW, S. Applied Logistic Regression, 2 ed., New York: Chichester, Wiley, 2000.

HSU, C-L.; LIN, J. C-C. Effect of perceived value and social influences on mobile app stickiness and in-app purchase intention. Technological Forecasting and Social Change, v. 108, jul., 2016. p. 4253.

KAHLE, L. R.; KENNEDY, P. Using the list of values (LOV) to understand consumers. Journal of Consumer Marketing. v. 6, n. 3. p. 5-12. Summer 1989.

LEIGH, J.H.; GABEL, T.G. Symbolic interactionism: its effects on consumer behavior and implications for marketing strategy. The journal of services Marketing, v. 3, n. 6, 1992.

LENNOX, R.; WOLFE, R. A revision of the self-monitoring scale. Journal of Personality and Social Psychology, v. 46, n. 6, p. 1348-1364, 1984. LEVY, S. J. Symbols for Sale, Harvard Business Review, p. 117-124, 1959.

LUNA-CORTÉS, G. The influence of symbolic consumption on experience value and the use of virtual social networks. Spanish Journal of Marketing-ESIC, v. 21, p. 39-51, 2017.

MATOS, C. A.; LEIS, R. P. Service failure recovery: a cross cultural study comparing Brazil and France. In: Encontro da ANPAD, Enanpad. Anais..., Rio de Janeiro, 2008.

MALHOTRA, N. K. Pesquisa de marketing. 4. ed. Porto Alegre: Bookman, 2006.

MCCRACKEN, G. Cultura e consumo: uma explicação teórica da estrutura e do movimento do significado cultural dos bens de consumo. Rev. Adm. Empresas, RAE, v. 47, n. 1, 2007.

MEHTA, R.; BELK, R. W. Artifacts, Identity, and Transitions: favorite possessions of indians and indian immigrants to the United States. Journal of Consumer Research, v. 17, March. p. 398-411, 1991.

MICK, D. G. Consumer research and semiotics: Exploring the morphology of signs, symbols, and significance. Journal of Consumer Research, v. 13, no. 2, 1986.

MILLAN, Elena; REYNOLDS, Jonathan. Self-construals, symbolic and hedonic preferences, and actual purchase behavior. Journal of Retailing and Consumer Services, v. 21, n. 4, p. 550-560, 2014.

MORGAN, G.; SMIRCICH, L. The case for qualitative research. Academy of Management. The Academy of Management Review. v. 5, oct, 4, 1980. p. 491.

PETTIGREW, S.; RYAN, M. M.; OGILVIE, M. New year's eve consumption plans: Consumers' consumption priorities on the eve of 2000. Australasian Marketing Journal, v. 9, n. 2, 2001.

PISCICELLI, L.; COOPER, T.; FISHER, T. The role of values in collaborative consumption: insights from a product-service system for lending and borrowing in the UK. Journal of Cleaner Production, $v$. 97, p. 21-29, 2015.

ROBERTS, J. A.; MANOLIS, C.; PULLIG, C. Contingent self-esteem, self-presentational concerns, and compulsive buying. Psychology \& Marketing, v.31, n.2, p. 147-160, 2014.

SCHMITT, B. Experiential marketing. Journal of Marketing Management v.15, n.1-3, p. 53-67, 1999. 
SHARMA, R.; JHA, M. Values influencing sustainable consumption behaviour: Exploring the contextual relationship. Journal of Business Research, v. 76, p. 77-88, 2017.

SHERIF, M. The psychology of social norms. New York: Harper and Brothers, 1936. SOLOMON, M. The role of products as social stimuli: A symbolic interactionism perspective. Journal of Consumer Research , v.10, № 3, p. 319-327, 1983.

TREISE, D.; WOLBURG, J.; OTNES, C. Understanding the "social gifts" of drinking rituals: an alternative framework for PSA developers. Journal of Advertising, v. 28, n. 2, 17-31, 1999.

ZASUWA, G. Do the ends justify the means? How altruistic values moderate consumer responses to corporate social initiatives. Journal of Business Research, v. 69, n. 9, p. 3714-3719, 2016. 